\title{
American Grand Strategy after November 2012
}

\author{
William C. Martel
}

Published online: 9 August 2012

(C) Springer Science+Business Media, LLC 2012

The central narrative of the 2012 presidential election campaign in the United States is the recession, spending, and deficits. It takes no great leap of imagination to realize that foreign policy matters are secondary to the campaign.

An important consequence of the 2012 campaign is a growing sense of how much disorder exists in the world and how difficult foreign policy has become for the United States. What is clear today is that the world shows clear signs of increasing disorder, and equally clear that we do not have a consensus in American society on the principles or grand strategy that should guide our foreign policy.

For signs of disorder, consider the following events that have occurred recently. Syria is teetering near civil war, with thousands of people being massacred. The nuclear negotiations over Iran's efforts to develop nuclear weapons have collapsed. Russia under President Putin shows worrisome signs of growing authoritarian rule and government-sponsored repression against the opposition - one observer recently noted that Russian has returned the era of Stalin.

To complicate matters, several Europe economies, notably Greece, Spain, Portugal, Italy, and Ireland are in serious difficulties, while Europe faces a recession, $11 \%$ unemployment, and hundreds of billions in bank bailouts. Reports suggest that Greece may leave the Eurozone. On this side of the Atlantic, the U.S. economy remains mired in a deep recession with unemployment greater than $8 \%$ and job growth anemic.

Further, Russia and China are working in close coordination on foreign policy issues, and gaining influence. There are signs that Russia and China are working with Iran, Syria,

W. C. Martel ( $\square)$

The Fletcher School of Law and Diplomacy, Tufts University, 160 Packard Avenue,

Medford, MA 02155, USA

e-mail: william.martel@tufts.edu
North Korea, among others, as part of a fledging authoritarian axis of influence. For reasons related to Afghanistan and Iraq, Washington's esteem is in serious decline. Meanwhile, North Korea continues its active program of ballistic missiles and likely is planning another underground nuclear test. Lastly, it goes without saying that Afghanistan and Pakistan are highly unstable, while observers worry about "leakage" from Pakistan's nuclear arsenal to extremists. The list goes on.

The central problem, which one hopes the 2012 campaign might help to resolve, is that foreign policy is consumed by increasing disorder - and as a result, we have failed to develop clear principles to guide American foreign policy. It would be of great consequence for the United States if the 2012 campaign were to produce, perhaps during the campaign or sometime afterward, the outlines of a consensus on what principles should guide the United States in its foreign policy deliberations.

One reason for the confusion about foreign policy is dramatic shifts in the geopolitical, social, and economic fabric of the world. Such shifts serve to disorient policymakers, who nevertheless are required to adapt intellectually to these challenges. Part of the problem seems to be the unwillingness of policymakers to adopt new forms of strategic thinking - a result, perhaps, of clinging stubbornly to familiar approaches despite evidence all around us that the world is being shaped by profound uncertainties and growing disorder.

Today, many states, including the United States, make policy choices without an overriding grand strategy. This is, without doubt, an immensely dangerous development, given the sources of disorder in the world. Thus, now, more than ever, policymakers must come to grips with the new world that we occupy if the United States is to develop coherent guidance for navigating the challenges posed by the modern world. 


\section{Global Disorder and Failure to Build Consensus on Grand Strategy}

What the sources of this growing global disorder and failure to build a consensus on grand strategy? How, in other words, did the United States get to this point?

From the end of World War II until the late 1980s and early 1990s, the United States was guided by a highly coherent grand strategy. The essence of American strategy, as George Kennan outlined, was to contain the Soviet Union in ideological, political, military, and economic terms. Despite anxieties at the time, it proved to be an immensely successful strategy, particularly when the Soviet Union collapsed unexpected and was formally dissolved on December 31, 1991

This period was remarkable for the deep consensus in American society and among our allies on the overall content and nature of our grand strategy. Today, however, we have no such accord. By contrast, U.S. policymakers have adopted policies that rely on the remnants of containment or, more frequently and perhaps more alarmingly, on piecemeal responses to challenges. Occasionally, we ignore certain challenges altogether.

The rule during the Cold War was that the United States and its allies confronted risky, but largely predictable, circumstances if they made serious mistakes in foreign policy. Today, however, policymakers face a world characterized by much greater unpredictability, but dangerously is it governed by the misleading belief that the risks are so low or shared with other global actors that the world has become more benign and less dangerous.

Nuclear war, for example, between the superpowers, is about as unlikely as matters get. What has replaced the clear-cut nuclear deterrence balance between the superpowers, however, is a wide range of more inchoate and uncertain risks - nuclear proliferation into the hands of new actors as well as possible stand-offs between nucleararmed regional powers.

While once central to grand strategy in an era of global competition, nuclear issues no longer provide a solid conceptual point in foreign policy. Without clear and decisive threats on the scale faced by the United States and its allies during the Cold War, the once-uncontested organizing principles of grand strategy are practically irrelevant and have been discarded altogether.

To complicate the problem, several developments suggest that the world is becoming not simply more disorderly, but highly unstable as well. For example, regional powers such as Iran and Pakistan have joined Russia and China as states of great concern to policymakers in Washington.

What these factors suggest is that the United States needs to undertake a broad reevaluation of its grand strategy. As these shifts in the global order continue to cascade upon each other, there are many questions that societies and their policymakers can no longer avoid. How do we formulate a grand strategy for managing a world that shows signs of increasing disorder? What principles should govern foreign policy? What choices should societies make? How do we create some order out of the emerging disorder? My view is that presidential campaigns and the aftermath provide an opportunity for the American people and their policymakers to reexamine who we are, what we believe, and how we want to conduct ourselves in foreign policy. At a time of great uncertainties, it is essential for policymakers to answer these questions if they seek to preserve peace, security, freedom, and prosperity for this and subsequent generations.

\section{Principles for Organizing Grand Strategy}

The best place to begin is with what is known as grand strategy, which in effect provides principles that help policymakers and their society to organize issues in a useful way for the conduct of foreign policy. Before we begin, there are, however, differing ways to tackle this problem.

For some scholars and policymakers, the solution is to organize our thinking by focusing on the states that pose the greatest challenges. For others, however, the preferred approach is to examine what we often call transnational issues - this includes such challenges, as proliferation or extremism, which transcend individual states and regions.

For still others, the best approach is to focus on regions, such as Asia and the Middle East. The problem is that such linear approaches often are not terribly useful because they promote fairly prosaic, "school solutions" to foreign policy challenges. Facing systemic disorder in contemporary international politics, we have moved well beyond the point where policymakers and societies can use old solutions to new problems.

Rather than using the timeworn approaches of focusing on states, issues, and regions that threaten U.S. interests, this essay moves in a different direction. The first step in formulating a grand strategy is to define the fragmented, fragile, and disordered world into what will be called "sources of disorder."

In practice, these categories may help policymakers overcome the current state of confusion by focusing on the broad outlines of challenges that will help the United States formulate a coherent grand strategy. Yet, policymakers must ensure that grand strategy deals with complexities while establishing guidance that helps policymakers formulate policies for dealing with sources of disorder. The problem is that disorder has 
undermined the prevailing vision of foreign policy. And worse, it has demoralized the present generation of policymakers who have failed, despite valiant efforts, to formulate a coherent grand strategy.

\section{Expected but Still Destabilizing Shifts}

Grand strategy should help policymakers deal with the expected ebbs and flows in world politics. While such shifts are routine in the normal discourse of geopolitics, these have destabilizing consequences for policymakers who must be mindful in the post-2012 campaign of several sources of disorder.

Foremost among these changes is the threat of rising states that pose a challenge to American power. The rise of China is undoubtedly the most prominent example. Beijing's growing economy, the second largest in the world, increased spending on defense, and growing global footprint in development and energy affirm that China is a power to be reckoned with.

The next most prominent case is that of a resurgent Russia. Under President Putin's tutelage, Russia has engaged in increasingly strident rhetoric toward the United States, used predatory energy policies toward Europe, and employed reckless language about nuclear weapons - all of which foment deep concern in capitols across Eurasia. Working closely with China, the emerging SinoRussian axis uses their vetoes in the United Nations to undermine U.S.-led initiatives for dealing with the civil war in Syria and Iran's presumed nuclear weapons program. Some leaders in Asia and Europe fear that Russia's power is on the rise, the United States is weak and distracted, and current tensions may herald the dawn of a second Cold War.

To the category of the expected but destabilizing challenges we must add a new dimension. The emergent problem today is the possibility that small states, which do not simply act as proxies for larger adversaries, may become on their own sources of disorder that threaten the great powers and undermine global security.

Iran is perhaps the best and most prominent case. With its nuclear weapons and missile programs and harsh rhetoric toward Israel and the United States, many states in the region worry that Tehran's reckless policies could foment war and devastation. Saudi Arabia, Turkey, and Egypt worry that a nuclear-armed Iran will become a regional hegemon, which leads to hints that they also might move to develop nuclear weapons. With the West's dependence on Middle East oil, Tehran could contribute to disorder if it unleashed extremist groups in response to a military attack against Iran's nuclear complex.
North Korea remains the perpetually difficult case. With its isolated and insular regime, unknown and inexperienced leader Kim Jung Un, active programs for building ballistic missiles and nuclear weapons, moribund domestic economy, prolific international trade in illicit goods, and demonstrated aptitude for winning diplomatic concessions from the international community - Pyongyang has a pronounced ability to create disorder. We might say that North Korea has a profound ability to disrupt the balance of power in Asia or provoke a regional war.

Pakistan remains an immensely dangerous case, which has the ability to foment instability and war. With the forces of political destabilization, active support for such extremists as the Taliban and Al Qaeda in Afghanistan, and the West's existential fears that its arsenal of perhaps $100 \mathrm{nu}$ clear weapons could fall into the hands of extremists Pakistan is a source of disorder that could drag the United States into a crisis.

The Western hemisphere is not immune to potentially destabilizing shifts. Washington faces problems on its border with Mexico from drug cartels, daily spasms of violence, and waves of illegal immigration. Further south, President Hugo Chavez of Venezuela has radicalized politics in Latin America with his economic support for socialist, anti-American governments. In aligning Venezuela with Russia, China, and Iran, he has changed Venezuela's role in global politics. At the same time, he is ill and Venezuela's oil industry has been dramatically weakened.

The central challenge for grand strategy facing these sources of geopolitical disorder is an eminently practical one: how does the United States manage the challenges from great powers and lesser states, since both categories can harm U.S. interests? And can the United States do so in the midst of the 2012 presidential campaign?

\section{Unexpected Surprises and Uncertainties}

In contrast to this serious of expected challenges in geopolitics, American grand strategy must deal with a second and more difficult set of challenges. These involve more paradigmatic changes in political and social structures that can magnify the problems caused by individual states.

After the Cold War, policymakers believed the world would be largely less dangerous. During the late 1980s and early 1990s, scholars argued that communism's collapse would unleash the "end of history." This view masked the hope that the world, with the ascent of the forces of liberal democracy and free markets, would become more peaceful.

The decline in the attention that American scholars and policymakers paid to global threats lasted for one decade until the relative peace was shattered by $9 / 11$, which 
signaled the beginning of the war against extremism. During the last decade, the international community has struggled to organize its efforts to deal with an unending stream of both unexpected and destabilizing developments. Quite predictably, recent events demonstrate that grand strategy must prepare the state for dealing with unexpected surprises in addition to gradual geopolitical shifts.

Consider several examples in the category of unexpected sources of disorder today. We face the very real possibility that there will be a resurgence of extremists in Afghanistan along with its political collapse. What happens in Afghanistan is fundamentally unknown in view of widespread corruption in Afghanistan's government under President Hamid Karzai, doubts about the United States has the resolve to fight in Afghanistan for the foreseeable future, and the Taliban's enduring commitment.

The emergence of the Arab Spring and the challenges of democratization in societies ruled by authoritarianism and extremism is an unexpected development in foreign policy. We are relearning that revolutions evolve in unpredictable directions in developing societies, and that democratization is difficult and uncertain. Even if the Arab Spring leads to democratization in Egypt and Libya, policymakers must be careful what they wish for. The rise of the Muslim Brotherhood in Egypt demonstrates that democratization is a long and difficult process, which poses medium to long-term dangers for security in the Middle East.

To the category of unexpected surprises and uncertainties, especially in the midst of the U.S. presidential campaign, the architects of grand strategy must expand their thinking to include developments in the global economy. Since the beginning of the Cold War, economic considerations were subordinated entirely to political and military considerations. Today, however, economic issues are central to grand strategy.

The modern global economy presents the possibility that we may see another dramatic shift. In 2012, we face the deepest recession, longest period of high unemployment, and most anemic economic recovery since the Great Depression. In the decades since the 1930s, the economic dimension of grand strategy was not foremost in the minds of policymakers. But that has changed with the economic disorder that puts the global economy, prosperity, and peace at risk.

Europe faces an unparalleled crisis. In the Eurozone, countries such as Greece confront economic collapse, political violence and social disorder, and could in theory depart from the European economic and monetary union. As a result of globalization, economic crises can ripple around the globe with unprecedented speed to affect all societies.

In Asia, policymakers have to calculate whether China's growth will prove sustainable or whether it is an example of another economic bubble. With its export-driven economy, China's fundamental political stability rests directly on the health of the global economy, notably the ability of other countries to purchase Chinese goods. As a result of dense webs of economic interdependence in the global economy, any failure in China's economy will have devastating global consequences.

\section{New Challenges from Globalization and Technology}

Grand strategy must deal with another new category, which falls between the expected and unexpected. While policymakers assumed that technology and globalization would substantially affect the world, understanding and predicting how exactly those changes would influence geopolitics is not a science. Such changes will continue for the foreseeable future and while we still do not know the exact effects in the long term, it is highly likely that they will be profound. There already are signs of the emergence of game-changing trends.

Facing an era of extraordinary progress in the internet and in communication technologies, along with the increasing affordability and accessibility of technologies in general, policymakers must formulate a grand strategy that helps them deal with an era in which power relationships between individuals, firms, and states gradually flatten.

States seem less influential, while with the emergence of new technologies, non-state actors are gaining greater ability to disrupt security. The prominent example is the risks posed by weapons of mass destruction and cyber warfare in the hands of non-state actors.

Grand strategy must be able to deal with mounting domestic and international pressure for governments to practice transparency in all cases of policy. However, policymakers need to guard state secrets and protect sensitive information vital to the state's security, its population, and its citizens and soldiers abroad. The global media and the $24 / 7$ news cycle puts pressure on states to strike the right balance between transparency and caution.

\section{Further Complications for Grand Strategy}

Several conditions further complicate how the United States moves to formulate its grand strategy. One is the tension between wanting to act in concert with other states and the international community while preserving one's options to act alone, if necessary.

This principle is evident with the U.S. strategy toward Iran as Washington seeks to bolster its relationship with the members of the $\mathrm{P} 5+1$ group, while retaining the ability to 
act alone. Consider the case of NATO, whose role is less clear but which remains an instrument for working in collaboration with other states while not relinquishing the ability to act independently.

Consider the entrenched political polarization in Washington that complicates and paralyzes all cases of U.S. policy. While the United States historically conducted its foreign policy on largely bipartisan terms, we now see divisions on virtually all issues. For now, Washington has not been able to move beyond this polarized environment, which puts at stake its ability to act with one voice on foreign policy.

Lastly, there are several global flash points that can fuel dangerous escalatory conflicts beyond their localized origins. Despite the general yearning for peace, the potential for armed clashes is very high, as states have unchecked areas of fragility could provoke crises. In Asia, an India-Pakistan conflict could involve the United States and China as see by a crisis between China and Taiwan in the Taiwan Strait. A crisis with North Korea could draw in China, Russia, Japan, South Korea, and the United States. In the Middle East, Iran's nuclear and missile programs constitute a flashpoint that could involve the United States, Israel, Egypt, Saudi Arabia, Turkey, and Gulf Cooperation Council (GCC) states. The same logic applies to crises involving Iraq, Afghanistan, Egypt, Libya, and Syria.

\section{Anxiety without Grand Strategy}

When societies conduct foreign policy in a world characterized by such disorder and operate without a coherent grand strategy, they naturally will fall prey to anxieties. How could states, which could be the victims of this increasingly disordered world, and yet lack a strategy to guide their actions, feel or act otherwise? Disorder without strategy is a recipe for disaster.

To start, Americans generally want to exercise leadership, but today it is hard to tell whether the society and their policymakers are willing and able to make that sacrifice. Worse, it is difficult to formulate a grand strategy when we do not have a coherent framework for relating the arc of problems to world politics.

The United States will remain in an intellectual limbo until it learns how to build a grand strategy that can deal with the sources of disorder. Beyond the usual domestic political differences, one source of political polarization in Washington is deep uncertainty about what really matters in foreign policy.

Americans are especially vulnerable to weariness from the daily grind of foreign policy, the more so when their actions are not guided by a positive vision of foreign policy. One sign of weariness is that, according to public opinion polls in June 2011, only $11 \%$ of Americans believed the U.S. should be the world's policeman. In 2012, $69 \%$ favor the use of military force overseas only when U.S. security is threatened.

Dangerously, the United States has been adrift for more than two decades, operating without a positive and reassuring vision for its foreign policy. How can policymakers expend resources - by which I mean "blood and treasure" - when it is not clear why they are doing so and for what purposes?

Americans clearly have grown tired of war and weary of economic hard times. Beyond this decade of war, preceded by more than four decades of the Cold War, World War II, and World War I - the American people spent virtually all of the twentieth century fighting wars, hot and cold, and providing global leadership, often well beyond what other states were willing or able to provide.

Without a vision of what to accomplish in foreign policy, it is a virtual law of nature that societies lose focus, a sense of purpose, and strategic momentum. What happens next is a sense of perpetual drift, as foreign policy swings from fighting wars (Afghanistan and Iraq) to public discontent with such involvement. In 2012, $56 \%$ support the withdrawal of most U.S. forces from Afghanistan by 2014 .

\section{Regain Consensus on American Grand Strategy}

Lastly, the failure to develop a grand strategy fuels debates about America's decline. The United States faces grinding wars without end, a deep economic recession, the emergence of authoritarian powers such as China and Russia (perhaps as the leaders of a new authoritarian axis with Iran, Syria, North Korea, and Venezuela), deep worries about the future, and no clear sense of purpose. It is any wonder that the American people and their leaders wonder whether they should bear the mantle of global leadership?

What emerges from this argument is that the United States cannot afford to run the risks that follow from a foreign policy that is not grounded in a broad vision of what we seek to accomplish in the world. Such visions emerge either from a crisis or from electoral politics. My hope is that the 2012 presidential campaign may provide some help in guiding the United States toward a more coherent idea of what principles will define our conduct in foreign policy.

Such campaigns provide an opportunity for candidates to explore their visions of foreign policy and for the society to consider which ideas they find to be more conducive to their own image of America's role in 
global affairs. Indeed, an aspiration for the United States is to see some debate about our role in the world, and to see emerge an outline of the principles of a positive vision for the United States and its allies that will guide our choices in foreign policy. Only then will observers be able to say that the United States is moving in the direction of building a consensus on grand strategy. In reality, we really have no choice given the magnitude of the problems that we face.

William C Martel Associate Professor of International Security Studies at The Fletcher School of Law and Diplomacy at Tufts University, is the author of Victory in War: Foundations of Modern Strategy (New York: Cambridge University Press, 2011). 